\title{
NEGÓCIOS JURÍDICOS PROCESSUAIS E A MODULAÇÃO DO PROCEDIMENTO NAS AÇÕES COLETIVAS
}

\author{
Tereza Cristina Sorice Baracho Thibau ${ }^{1}$ \\ Thaís Costa Teixeira Viana ${ }^{2}$
}

\section{RESUMO}

O Código de Processo Civil de 2015, visando concretizar o escopo constitucional da garantia de devido processo legal, introduziu no ordenamento brasileiro a possibilidade de celebração de negócios jurídicos processuais, que, homologados, vinculariam partes e juiz. Sabe-se, contudo, que, no âmbito da tutela processual de direitos coletivos em sentido lato, as normas processuais civis somente encontram aplicabilidade subsidiária, naquilo em que não forem com ela incompatíveis. O presente trabalho objetiva, portanto, averiguar a compatibilidade entre esse modelo de contratualização do processo e as ações coletivas, por intermédio de análise interdisciplinar, jurídico-dogmática, pautada pela noção de devido processo legal coletivo.

Palavras-Chave: Negócios Jurídicos Processuais. Devido Processo Legal. Princípio da Cooperação. Ações Coletivas. Acesso à Justiça.

\section{PROCEDURAL LEGAL AGREEMENTS AND THE MODULATION OF THE PROCEDURE IN CLASS ACTIONS}

\begin{abstract}
The 2015 Civil Procedure Code, aiming to concretize the constitutional scope of due process guarantee, has introduced in the Brazilian legal system the possibility of celebrating procedural legal agreements that, once homologated, would bind the parties and the judge. It is known, however, that, regarding the procedural protection of collective rights (in the broad sense), civil procedural rules would only apply subsidiarily, and if not incompatible. Therefore, the present research aims to verify the compatibility between this contractual model of the process and class actions, throughout an interdisciplinary and legal-dogmatic analysis, based on the notion of due collective process.
\end{abstract}

Key-Words: Procedural Legal Agreements. Due Process. Principle of Cooperation. Class Actions. Access to Justice.

\section{INTRODUÇÃO}

\footnotetext{
${ }^{1}$ Doutora e Mestre em Direito pela UFMG. Professora Associada de Direito e Processo Civil e Coletivo na FDUFMG. Membro do IDPro (Instituto de Direito Processual). Bacharela em Pedagogia pela PUC-Minas.

${ }^{2}$ Mestranda e Bacharela em Direito pela Universidade Federal de Minas Gerais. Pesquisadora do Programa Universitário de Apoio às Relações de Trabalho e à Administração da Justiça (PRUNART-UFMG). Advogada.
} 
A recente entrada em vigor do Código de Processo Civil de 2015 (CPC/15), além de introduzir novos instrumentos à tutela processual de direitos, importou a remodelação das bases principiológicas sobre as quais se alicerça todo o sistema processual brasileiro. O novo diploma legislativo erigiu ao patamar de normas fundamentais do processo civil a busca pela resolução consensual de conflitos (art. $\left.3^{\circ}, \S 2^{\circ}, \mathrm{CPC} / 15\right)$, a duração razoável do processo (art.4 $\left.4^{\circ}, \mathrm{CPC} / 15\right)$, a boa-fé processual (art. $\left.5^{\circ}, \mathrm{CPC} / 15\right)$, a cooperação entre os sujeitos do processo (art.6 $\left.{ }^{\circ}, \mathrm{CPC} / 15\right)$, dentre outros.

A partir do substrato jurídico estruturado como consequência da aplicação sistêmica e conjunta dessas normas fundamentais, foram idealizados os novos instrumentos processuais e revisitados os antigos institutos, os quais passaram a merecer, com ainda maior imprescindibilidade, interpretação à luz da unidade do diploma legal no qual estão inseridos (THEODORO JUNIOR et al, 2015, p.19), sobretudo com vistas a se garantir efetividade e eficiência na condução e gestão de processos judiciais, em meio à cultura de judicialização de conflitos que ainda predomina no ordenamento jurídico brasileiro.

Com fulcro nessas novas premissas que passaram a reger o processo civil brasileiro, e se motivando na busca pela maior efetividade processual, a partir da ampliação da participação das partes no procedimento judicial, foi introduzida no ordenamento jurídico a noção de 'contratualização do processo', pautada pela possibilidade de se celebrar negócios jurídicos processuais envolvendo concessões mútuas acerca de aspectos do procedimento, podendo-se citar, a título de exemplificação, a calendarização do processo, o saneamento compartilhado e a convenção das partes acerca da distribuição do ônus de prova.

Referidos institutos, não há dúvidas, foram idealizados, a princípio, com vistas a se inserirem em procedimentos judiciais voltados à tutela individual de direitos, mormente se for tido em consideração que, após o veto do art. $333^{3}$, não se encontram no CPC/15 dispositivos voltados especificamente à tutela de direitos coletivos. No entanto, igualmente inquestionável é a aplicação subsidiária das normas processuais comuns ao microssistema de tutela de direitos coletivos em sentido lato, naquilo em que não forem com ele incompatíveis, considerando-se o caso específico do CPC/15 que, ao contrário do Código de Processo Civil de 1973 (CPC/73), já foi editado tendo-se consciência da existência desse microssistema, como bem pontuado por DIDIER JR. e ZANETI JR. (2016, p.18), nas suas Notas à 10 Edição da obra Curso de Direito Processual Civil - Processo Coletivo:

\footnotetext{
${ }^{3}$ Previa a possibilidade de o juiz converter ações individuais em coletivas.
} 
Embora o CPC-2015 não se dedique ao processo coletivo, não se pode ignorar uma circunstância histórica que o torna bem diferente dos anteriores códigos brasileiros de processo: este é o primeiro código que nasce pressupondo a tutela coletiva, incorporando uma boa parte de técnicas processuais antes previstas apenas para o âmbito coletivo e trazendo inúmeras inovações que podem aperfeiçoar bastante a tutela de direitos coletivos.

Portanto, exsurge o questionamento acerca da compatibilidade ou não entre esses institutos recentemente inseridos no ordenamento brasileiro, e a sistemática processual voltada à tutela de direitos coletivos (difusos e coletivos em sentido estrito) e à tutela coletiva de direitos (individuais homogêneos), conforme leciona ZAVASCKI (2014). No que concerne à celebração de negócios jurídicos processuais, interroga-se também, acerca de seu potencial para promover o acesso das coletividades à justiça e dos limites de sua eventual aplicabilidade no âmbito de ações coletivas.

Face à escassez doutrinária acerca da temática, o presente trabalho objetiva averiguar a possibilidade e eventuais limites à celebração de negócios jurídicos processuais no âmbito de ações coletivas, analisando-se sua compatibilidade com a noção de devido processo legal coletivo e seu potencial à efetivação do acesso das coletividades à justiça.

Nesse sentido, a partir de análise interdisciplinar (perpassando o direito processual civil individual e coletivo, além do direito constitucional), de viés jurídico-dogmático, a pesquisa abordará a interpretação da garantia constitucional do devido processo legal, pontuando noções intrínsecas à ideia de 'devido processo legal coletivo', além de avaliar o paradigma de estímulo à contratualização do processo, introduzido pelo CPC/15, à luz da base principiológica na qual se insere e das espécies de negócios jurídicos processuais previstas em lei. Por fim, avaliar-se-á a aplicabilidade desse novo paradigma ao microssistema de tutela processual de direitos coletivos em sentido lato, considerando-se sua potencialidade à promoção do acesso de coletividades à justiça.

O papel do Direito como implementador de políticas públicas envolve a produção legislativa voltada a concretizar o acesso à justiça, o que inclui a promoção da igualdade entre os jurisdicionados, inclusive no âmbito dos procedimentos judiciais. Nesse sentido, as ações coletivas claramente são meio de coibir desigualdades na distribuição da Justiça, à medida que trazem solução isonômica a todos os afetados por condutas lesivas a bens jurídicos comuns. Qualquer alteração legislativa que amplie as prerrogativas dos legitimados face ao 
procedimento judicial em defesa das coletividades, contribui ao melhor desempenho da função destes em busca da democratização do acesso à justiça. Por isso, a relevância de se verificar a repercussão, nas ações coletivas, da alteração legislativa que veiculou a possibilidade de celebração de negócios jurídicos processuais voltados à modulação do procedimento.

\section{A GARANTIA CONSTITUCIONAL DO DEVIDO PROCESSO LEGAL NA TUTELA DE DIREITOS INDIVIDUAIS E NA TUTELA DE DIREITOS COLETIVOS}

A Constituição da República de 1988 (CR/88) assegura a todos, indivíduos ou coletividades, indistintamente, em seu art. $5^{\circ}$, LIV, a garantia do devido processo legal, como condição à privação a qualquer espécie de bens ou liberdade, se revestindo da natureza de princípio fundamental sobre o qual se erige o ordenamento jurídico processual brasileiro.

A partir da noção de devido processo legal, compreende-se uma proteção aos jurisdicionados no sentido de que não poderão se ver privados de seus direitos de forma arbitrária e que obstaculize seu acesso à ampla defesa e contraditório - também princípios constitucionais, que se encontram intrinsecamente relacionados à ideia de devido processo legal. Em outras palavras, por intermédio do devido processo legal, estabelece-se o processo enquanto instrumento a serviço dos direitos dos jurisdicionados, aos quais deverá ser garantido o efetivo acesso a todas as suas etapas, conforme previsto em lei.

Não se confunde a ideia de devido processo legal, contudo, com a exigência de um formalismo exacerbado no tratamento judicial de conflitos. Pelo contrário, este princípio regente da sistemática processual brasileira demanda inquestionável sensibilidade dos operadores do Direito, a quem incumbe identificar as circunstâncias nas quais o excesso de formalismo importa obstáculo intransponível ao acesso à justiça, sob pena de se cultivar sistemática que encontra no processo um fim em si mesmo.

Neste sentido, inclusive, as ponderações de BEDAQUE (2010, p.26):

[...] processo não é, e nem poderia ser, somente forma. Toda a organização e a estrutura desse mecanismo encontram sua razão de ser nos valores e princípios constitucionais por ele incorporados. A técnica processual, em última análise, destina-se a assegurar o justo processo, ou seja, aquele desejado pelo legislador ao estabelecer o modelo constitucional ou devido processo constitucional. 
Tem-se que a plena observância do devido processo legal não reside meramente na submissão de todo e qualquer conflito ao crivo do Poder Judiciário, onde perpassará sequência estanque de etapas processuais previstas em lei. Pelo contrário, traduz muito mais a exigência de se submeter o tratamento judicial de conflitos à principiologia constitucional que rege o Estado Democrático de Direito, no sentido de se garantir às partes pleno acesso à justiça, à luz da ampla defesa e do contraditório, com vistas à obtenção da prestação jurisdicional definitiva e do acesso ao direito tutelado em razoável lapso temporal.

Transpondo-se a concepção de devido processo legal ao contexto das ações coletivas, verifica-se a necessidade de se proceder a determinadas adaptações, com o intuito se de garantir a efetividade da prestação jurisdicional às coletividades. Considerando-se que, nestas ações, os interesses das coletividades são tutelados em juízo por entes intermediários e a decisão proferida ao final deverá produzir efeitos que alcancem os titulares dos direitos, “ausentes" na relação processual, foi necessário que o microssistema de tutela processual de direitos coletivos revisitasse alguns institutos da processualística civil comum, a fim de munir o procedimento de condições que lhe garantissem efetividade.

As lições de GRINOVER (1987, p.196) demonstram que, desde os primeiros traços de estruturação do referido microssistema, não se haveria que cogitar incompatibilidade entre a noção de "devido processo legal" e as técnicas processuais das ações coletivas. Já em 1985, institutos processuais como a legitimidade ad causam, a coisa julgada e a competência receberam nova roupagem, com a edição da Lei de Ação Civil Pública (LACP/85), a fim de se adequarem à proteção em juízo de direitos de coletividades. Referidas normatizações, subsequentemente, foram complementadas pelo Código de Defesa do Consumidor em 1990 (CDC/90), já na vigência da CR/88.

Nesse sentido, DIDIER JR. e ZANETI JR. (2016, p.97) consideram que o devido processo legal coletivo se alicerça em princípios autônomos, que transcendem aqueles aplicados ao restante da processualística civil:

Alguns aspectos desse devido processo legal coletivo merecem destaque, constituindo em verdadeiros princípios autônomos do direito processual coletivo, não obstante extraídos da mencionada cláusula geral (de resto, como todos os demais princípios processuais). São eles: princípio da adequada representação, princípio da competência adequada, princípio da certificação adequada, princípio da informação e publicidade adequadas e o princípio da coisa julgada diferenciada com a extensão secundum eventum litis da decisão favorável ao plano individual. 
A sistemática introduzida pelo $\mathrm{CPC} / 15$ promoveu alterações no procedimento das ações submetidas ao crivo do Poder Judiciário, estabelecendo, inclusive, arcabouço de normas fundamentais a regerem o processo, tudo isso com vistas a conceber rito processual que fosse mais qualificado a garantir aos jurisdicionados o devido processo legal idealizado pelo constituinte, consentâneo às premissas do Estado Democrático de Direito.

\section{O CÓdigo De PROCESSO CIVIL DE 2015 E O NOVO PARADIGMA DE CELEBRAÇÃO DE NEGÓCIOS JURÍDICOS PROCESSUAIS}

A ideia de se promover ajustes ao procedimento por iniciativa das próprias partes não é algo absolutamente inédito no ordenamento jurídico brasileiro. Já o CPC/73 trazia previsão, em seu art.158, acerca da possibilidade de se haver constituição, modificação ou extinção de direitos processuais, em decorrência de declarações de vontade unilaterais ou bilaterais das partes. Entretanto, analisando-se de forma sistêmica referido Código, era também possível depreender que estas declarações de vontade compreenderiam, quando muito, pedidos de desistência e de suspensão do processo, por exemplo.

O CPC/15, por outro lado, uma vez promulgado, apesar de ter mantido, em seu novo art.200, a redação do antigo art.158 do CPC/73, tornou clara a possibilidade de haver maior espaço de interferência dos sujeitos do processo no procedimento judicial, do que simplesmente aquele de se pedir a desistência, renunciar ou pedir suspensão. Pelo contrário, introduz as noções de calendarização do processo e de saneamento compartilhado, que serão tratadas adiante, tornando mais democrática a condução do processo.

Essa ampliação pelo $\mathrm{CPC} / 15$ da possibilidade às partes (em conjunto com o juiz, conforme o caso), de modular o rito processual previsto em lei, por intermédio de negócios jurídicos processuais, constitui evidente reflexo da mudança de paradigmas introduzida pelo referido diploma legal, com o estímulo a um modelo de processo judicial comparticipativo e cooperativo (THEODORO JUNIOR et al, 2015, p.69), alicerçado na boa-fé dos sujeitos que o integram (art.5 $\left.5^{\circ}, \mathrm{CPC} / 15\right)$, sem se afastar da noção de devido processo legal:

Uma objeção que parece ganhar destaque contra o uso e o emprego da "contratualidade" do procedimento vem daqueles que entendem haver uma inconstitucionalidade por suposta ofensa ao devido processo legal e a 
segurança (previsibilidade) jurídica. Esse argumento se apoia justamente, em uma noção rígida dentro da qual apenas um sistema de regras hermeticamente estabelecido poderia promover para os litigantes a expectativa de segurança/previsibilidade acerca da condução do processo pelo magistrado. Somente poderia ser acatada caso o contrato não obedecesse o formalismo democrático, com o respeito ao conteúdo dos direitos fundamentais nas contratações. (THEODORO JUNIOR et al, 2015, p.268)

Foram reestruturados os pilares sobre os quais se sustenta a processualística civil, a fim de se instituir um novo paradigma de processo distanciado das noções de protagonismo judicial ou das partes, e centralizado na concepção de participação ativa, integrada e cooperativa dos sujeitos participantes da relação jurídico-processual (THEODORO JUNIOR et al, 2015, p.80). Não se trata, contudo, de se desconsiderar o conflito como elemento inerente ao processo, mas de se restringir este conflito ao objeto da lide processual, não alcançando, portanto, a condução do procedimento - o qual, se ressalta, é voltado ao seu equacionamento, ou seja, à sua resolução. Sedimentou-se, assim, a compreensão de que, assentando-se a função social do processo em promover definitiva resolução aos conflitos, seria dever não apenas do julgador, como também e, principalmente, das partes, posicionar-se cooperativamente, com vistas a viabilizar amplo debate jurídico que proporcionasse ao julgador uma visão multifacetária do conflito, sob o pressuposto inafastável da boa-fé objetiva e processual, além do melhor interesse das partes.

Nesse sentido, as lições de THEODORO JUNIOR et al (2015, pp.80-81):

Uma das bases da perspectiva democrática, trazida no Novo CPC, reside na manutenção da tensão entre perspectivas liberais e sociais, impondo que a comunidade de trabalho deva ser revista em perspectiva policêntrica e comparticipativa, afastando qualquer protagonismo e se estruturando a partir do modelo constitucional de processo, induzindo a convivência de poderes diretivos e gerenciais do juiz, com uma renovada autonomia privada das partes e dos advogados (como, v.g., na cláusula de negociação processual art.190), mediante as balizas do contraditório como garantia de influência (art.10) e na fundamentação estruturada (art.489) que fomentarão o melhor debate de formação decisória e poderá permitir a diminuição das taxas de recursos, além de impor a diminuição do retrabalho processual na medida em que todos deverão exercer na primeira vez sua atividade com alta responsabilidade.

Como consequência, tornou-se claro no bojo do próprio texto legislativo, que não poderia ser o processo judicial interpretado como uma arena de conflitos e de estímulo à 
litigiosidade, mas como um instrumento voltado à pacificação social desses conflitos, razão pela qual demandaria rito procedimental que estimulasse a consecução desse propósito. Por óbvio, a imposição de rito processual estanque e marcadamente burocratizado, apesar de almejar a concessão de tratamento indistinto aos litigantes, por vezes também pode importar prolongamento improdutivo do processo judicial.

Com fulcro nessas premissas, ampliou o $\mathrm{CPC} / 15$ a possibilidade de realização de negócios jurídicos processuais pelos sujeitos do processo, por intermédio dos quais se tornaria possível proceder a determinadas adequações no procedimento, tornando-o mais democrático (THEODORO JUNIOR et al, 2015, p.225) e adaptado às particularidades do caso concreto, sem prejuízo da garantia de devido processo legal, o que, nas palavras da doutrina de ANDRADE (2016, p.53), tornaria a Justiça mais cidadã e proporcionaria maior aceitabilidade social das decisões judiciais:

Todo esse quadro leva, ao menos em tese, à maior eficácia da ação pública, com a possibilidade de melhor aceitação das decisões judiciais, em razão da abertura democrática que se produz no Judiciário, tornando a justiça mais "cidadã" e enquadrando a função judiciária no novo modelo de Estado que se desenha neste início de século XXI: o Estado mediador. [...]

Ademais, a partir do clima consensual, também se combate um dos males modernos do processo: os recursos. Como o ajustamento de pontos importantes no processo se dá por meio do consenso, as partes tendem a não apresentar recursos contra decisões proferidas em tal contexto.

Percebe-se, portanto, a clara compreensão da doutrina de que a abertura de espaço aos litigantes, para que tenham maior prerrogativa em interferir no tradicional rito procedimental previsto pelo legislador, produziria a compreensão de que não seria a sentença, proferida ao final, um ato unilateral e coercitivo do Estado, mas o produto de uma relação processual democrática, que teria se atentado às peculiaridades fáticas postas por ambos os polos do processo. Como consequência, na lógica desta compreensão, verificar-se-ia uma redução do volume de recursos a serem levados ao Tribunal ad quem, na medida em que se mitigaria a sensação de inconformismo por parte daquele que tenha sido sucumbente.

De toda forma, a confirmação ou refutação deste entendimento específico só será possível a partir da reiterada observância de dados estatísticos do Poder Judiciário ao longo dos anos, a fim de se constatar se haveria uma redução do volume de recursos, reiteradamente de forma concomitante à eventual ampliação da realização de negócios jurídicos processuais. 


\subsection{Espécies de Negócios Jurídicos Processuais no Código de Processo Civil de 2015}

A partir da análise dos dispositivos legislativos inseridos no $\mathrm{CPC} / 15$, percebe-se que foi estimulada a celebração de negócios jurídicos processuais, voltados à modulação do procedimento judicial a partir das especificidades da causa, para fins de se definir nova distribuição de ônus, poderes, faculdades e deveres. Nesse sentido, a redação do art.190:

Art. 190. Versando o processo sobre direitos que admitam autocomposição, é lícito às partes plenamente capazes estipular mudanças no procedimento para ajustá-lo às especificidades da causa e convencionar sobre os seus ônus, poderes, faculdades e deveres processuais, antes ou durante o processo.

Parágrafo único. De ofício ou a requerimento, o juiz controlará a validade das convenções previstas neste artigo, recusando-lhes aplicação somente nos casos de nulidade ou de inserção abusiva em contrato de adesão ou em que alguma parte se encontre em manifesta situação de vulnerabilidade.

(BRASIL, Lei n. ${ }^{\circ} 13.105$, de 16 de março de 2015 - CPC/15)

A leitura do dispositivo legal revela que teria o legislador, contudo, estabelecido como condicionante ao ajustamento do rito, o fato de versar a respectiva lide acerca de direitos que admitissem autocomposição. Por outro lado, não trouxe qualquer tipo de vedação quanto ao momento adequado à celebração de aludidos negócios jurídicos, mencionando, pelo contrário, que isso poderia se dar antes ou durante o processo.

Ao assim dispor, portanto, cogitou o legislador a hipótese de as partes, por exemplo, ao contratarem entre si no âmbito extrajudicial, já inserirem cláusula em ajustamento do procedimento a ser adotado em eventual relação jurídico-processual que possa ser instaurada entre elas. Hipótese semelhante já é, há muito, admitida pelo ordenamento jurídico brasileiro, com a possibilidade de inserção de cláusulas de eleição de foro ou convenção de arbitragem em contratos particulares.

Da mesma forma, a partir da leitura do art.190, é possível extrair que, ao mesmo tempo em que concede o legislador às partes a prerrogativa de ajustar em modulação de normas processuais, estabelece limites formais e materiais à celebração de referidos negócios jurídicos, na medida em que sua validade se encontra submetida ao controle judicial. Referido controle, nos termos da lei, independeria de qualquer provocação das partes, podendo ser realizado de ofício pelo julgador, ao qual é determinada a recusa de aplicação do negócio jurídico processual, caso vislumbre nulidades em seu conteúdo, ausência de equilíbrio entre as 
partes (no caso de ajustamentos que provoque a uma das partes flagrante vulnerabilidade) ou abusividade fundada em eventual inserção desta previsão em contrato de adesão.

Ao lado dessa norma geral de contratualização do processo, introduz ainda a ordem jurídica processual preconizada pelo CPC/15 a possibilidade de calendarização do processo judicial, no bojo do art.191:

Art. 191. De comum acordo, o juiz e as partes podem fixar calendário para a prática dos atos processuais, quando for o caso.

$\S 1^{\circ} \mathrm{O}$ calendário vincula as partes e o juiz, e os prazos nele previstos somente serão modificados em casos excepcionais, devidamente justificados. $\S 2^{\circ}$ Dispensa-se a intimação das partes para a prática de ato processual ou a realização de audiência cujas datas tiverem sido designadas no calendário.

(BRASIL, Lei n. ${ }^{\circ} 13.105$, de 16 de março de 2015 - CPC/15)

Tal norma propõe a fixação de calendário prévio, incluindo-se prazos e datas limites, para a realização de atos processuais, pelos quais será dispensada a intimação das partes.

Referida calendarização, diferentemente do que se dá com os demais negócios jurídicos processuais previstos no art.190, pressupõe o ajustamento entre as partes e o juiz, na medida em que, uma vez celebrado, vinculará todos estes, enquanto sujeitos integrantes da relação jurídico-processual. Como corolário lógico disso, poderia se alcançar a conclusão de que não estaria essa espécie de negociação submetida ao controle judicial a posteriori, haja vista já ter sido celebrada com a participação ativa do julgador.

Para além da calendarização (art.191, CPC/15) e da norma geral de contratualização do processo (art.190, CPC/15), pode-se encontrar, ainda, traços deste novo modelo de celebração de negócios jurídicos processuais, nas disposições dos parágrafos do art.357 do CPC/15, que introduzem ao processo judicial a noção de saneamento compartilhado.

Sob a égide do CPC/73, o saneamento do processo era realizado a partir da fixação, exclusivamente pelo juiz, dos pontos controvertidos, da decisão das questões processuais pendentes e da determinação das eventuais provas a serem produzidas. Tradicionalmente, ainda, referido saneamento se dava a partir da prolação de despacho saneador, após a conclusão dos autos ao juiz (apesar de, já desde 1994, ter sido inserida no bojo do procedimento, subsequentemente ao prazo para apresentação de defesa e às providências 
preliminares, audiência de conciliação, no transcorrer da qual já poderia ser saneado o feito, caso não alcançada a conciliação ${ }^{4}$ ):

\begin{abstract}
Se não houve controvérsia na fase postulatória, a respeito da admissibilidade da ação ou dos pressupostos processuais, bastará ao juiz, no saneador, proferir decisão sucinta em que afirme estar o processo em ordem, declarando-o saneado, em seguida. [...]

Com a instituição da audiência de conciliação (Lei n. ${ }^{\circ} 8.952 / 94$ ), o saneador poderá, em princípio, ser proferido oralmente pelo juiz, ficando o seu teor consignado na ata daquela audiência ( $\$ 2^{\circ}$ do art.331). Se, porém, o juiz preferir, poderá determinar conclusão dos autos para redigir, posteriormente, sua decisão. (THEODORO JUNIOR, 2012, pp.435-436)
\end{abstract}

Com o início da vigência do $\mathrm{CPC} / 15$, foi a fase de saneamento objeto de reorganização, a partir da introdução da ideia de um saneamento compartilhado, no qual a responsabilidade por sanear o feito é dividida entre o juiz e as partes (BRITO, 2016, p.118).

Na nova sistemática processual, na medida em que não se estiver diante de hipóteses de extinção do feito sem resolução de mérito ou de julgamento antecipado do mérito, proceder-se-á ao saneamento do feito, com a resolução de questões processuais pendentes, a delimitação das questões de fato sobre as quais recairá a produção probatória, a distribuição do ônus de prova, a delimitação das questões de direito relevantes e a designação de audiência de instrução e julgamento, se for o caso. Porém, distanciando-se do modelo tradicional, o $\mathrm{CPC} / 15$ faculta às partes promoverem o saneamento consensualmente, no que se refere à delimitação das questões de fato controvertidas e daquelas de direito relevantes, apresentando referido ajustamento ao juiz para homologação, a partir da qual os sujeitos do processo se vincularão (art.357, $\left.\S 2^{\circ}\right)$.

Sobre esta prerrogativa das partes, leciona BRITO (2016, p.124):

Trata-se, como de pronto se percebe, de aplicação do princípio da cooperação, uma vez que permite às partes, entre si, delimitar os pontos

\footnotetext{
4 “Art. 331. Se não ocorrer qualquer das hipóteses previstas nas seções precedentes, e versar a causa sobre direitos que admitam transação, o juiz designará audiência preliminar, a realizar-se no prazo de 30 (trinta) dias, para a qual serão as partes intimadas a comparecer, podendo fazer-se representar por procurador ou preposto, com poderes para transigir. (Redação dada pela Lei $n^{\circ} 10.444$, de 7.5.2002) $\S 1^{\circ}$ Obtida a conciliação, será reduzida a termo e homologada por sentença. (Incluído pela Lei $\mathrm{n}^{\circ} 8.952$, de 13.12.1994) §2 Se, por qualquer motivo, não for obtida a conciliação, o juiz fixará os pontos controvertidos, decidirá as questões processuais pendentes e determinará as provas a serem produzidas, designando audiência de instrução e julgamento, se necessário. (Incluído pela Lei $n^{\circ} 8.952$, de 13.12.1994) $\$ 3^{\circ}$ Se o direito em litígio não admitir transação, ou se as circunstâncias da causa evidenciarem ser improvável sua obtenção, o juiz poderá, desde logo, sanear o processo e ordenar a produção da prova, nos termos do $\S 2^{\circ}$." (BRASIL. Lei n. ${ }^{\circ}$ 5.869, de 11 de janeiro de 1973 - CPC/73)
} 
controvertidos. Para tanto, celebrarão um negócio jurídico processual, com vistas a organizar o procedimento.

De forma semelhante, determina o CPC/15 que seja convocada audiência para que o saneamento seja feito em cooperação entre o juiz e as partes, caso a causa apresente complexidade. Na oportunidade, permite-se ainda a produção de prova testemunhal.

Ainda dentre as hipóteses de negociação jurídica processual expressamente previstas pelo CPC/15, pode-se citar a convenção entre as partes acerca da distribuição do ônus de prova, prevista no art.373, $\S 3^{\circ}$. Nos termos do caput deste artigo e, seguindo-se a sistemática tradicionalmente adotada pela ordem processual, como regra, o ônus de prova incumbe ao autor, quanto aos fatos constitutivos de seu direito, e ao réu, quanto aos fatos impeditivos, modificativos ou extintivos do direito do autor. Entretanto, faculta o mencionado parágrafo terceiro do art.373 que poderão as partes distribuir esse ônus de forma diversa, com a condição de que não se esteja tratando de direito indisponível e não se torne excessivamente difícil a uma das partes a produção da prova que lhe tenha sido atribuída.

É relevante reiterar que, apesar de delimitar o CPC/15 expressamente algumas espécies de negócios jurídicos processuais, isso não impede que outros sejam celebrados entre as partes, mesmo porque o art.190 constitui norma geral de contratualização do processo.

\section{NEGÓCIOS JURÍDICOS PROCESSUAIS E SUA APLICABILIDADE NA TUTELA PROCESSUAL DE DIREITOS COLETIVOS EM SENTIDO LATO}

No ordenamento jurídico brasileiro, o microssistema de tutela processual de interesses coletivos em sentido lato estrutura-se ao redor das concepções de direitos difusos, coletivos em sentido estrito e individuais homogêneos, estabelecendo iter procedimental, portanto, adequado à proteção dessas modalidades de direitos. Referida classificação foi introduzida no texto legislativo pelo CDC/90, no bojo do parágrafo único de seu art.81, do qual se pode extrair que 'difusos' seriam aqueles interesses indivisíveis e com titulares indetermináveis ligados por circunstâncias de fato, 'coletivos em sentido estrito', aqueles indivisíveis com titulares determináveis ligados por relação jurídica base, e 'individuais homogêneos', os interesses divisíveis com titulares determinados e origem comum. As duas primeiras espécies compreenderiam interesses de natureza transindividual, ao passo que a 
última abarcaria direitos de natureza individual, tuteláveis coletivamente em razão de sua homogeneidade.

Com vistas a promover a satisfatória tutela processual destes interesses, nas décadas de 1980 e 1990 foram introduzidos no ordenamento jurídico brasileiro novos instrumentos processuais, bem como foram adaptados institutos processuais já presentes no CPC/73. Assim, determinou-se a regulamentação peculiar de institutos como a litispendência, a legitimidade ativa e a coisa julgada, além das regras de competência, tudo isso amparado pela aplicação subsidiária das normas processuais civis comuns ao microssistema compatíveis.

Ao tratar da estruturação desse microssistema, ZAVASCKI (2014, pp.14-15) considera que o processo civil passou por período de mudanças, dividido em duas fases:

\footnotetext{
As modificações do sistema processual civil operaram-se em duas fases, ou “ondas", bem distintas. Uma primeira onda de reformas, iniciada em 1985, foi caracterizada pela introdução, no sistema, de instrumentos até então desconhecidos do direito positivo, destinados (a) a dar curso a demandas de natureza coletiva, (b) a tutelar direitos e interesses transindividuais, e (c) a tutelar, com mais amplitude, a própria ordem jurídica abstratamente considerada. E a segunda onda reformadora, que se desencadeou a partir de 1994, teve por objetivo não o de introduzir mecanismos novos, mas o de aperfeiçoar ou de ampliar os já existentes no Código de Processo, de modo a adaptá-lo às exigências dos novos tempos.
}

Desde a vigência do $\mathrm{CPC} / 15$, seria possível considerar que, com base na classificação desse autor, estar-se-ia vivenciando uma terceira fase ou "onda" reformadora, em que as normas processuais comuns, que conferem regulamentação subsidiária às ações coletivas, teriam sido revisitadas, passando, inclusive, a se alicerçar em revigorada base principiológica, consoante já abordado. Como consequência, na medida em que se aplicariam ao microssistema estas novas normas, surgiu uma inadiável demanda por se analisar a compatibilidade entre estas e a proteção em juízo de interesses coletivos em sentido lato.

No que concerne especificamente à possibilidade de celebração de negócios jurídicos processuais, com o intuito de se modular determinados aspectos do procedimento previsto em lei, sua aplicabilidade no âmbito de ações coletivas deve ser analisada de forma minuciosa, com o fim de se impedir que a concretização de determinadas alterações no processo - ainda que mediante a anuência das partes - prejudique o interesse das coletividades que estejam sendo discutidos. Da mesma forma, faz-se mister averiguar se os próprios limites impostos 
pela legislação processual civil à celebração de negócios jurídicos processuais inviabilizaria a sua aplicação no âmbito de ações coletivas.

Ao se proceder à leitura do art.190 do CPC/15, percebe-se que, ao regulamentar o ajustamento entre as partes no sentido de se promoverem mudanças no procedimento, estipula como condicionante que a respectiva ação judicial (cujo procedimento se pretenda modular) verse sobre direitos que admitam autocomposição. Entretanto, trasladando-se esse requisito ao contexto do microssistema de tutela de direitos coletivos em sentido lato, percebe-se que ainda não encontraria a doutrina consenso acerca da possibilidade se de transigir envolvendo direitos transindividuais e individuais homogêneos no bojo de ações coletivas.

No sentido da inadmissibilidade de autocomposição envolvendo direitos coletivos em sentido lato, no âmbito de ações coletivas, pode-se citar o entendimento de ZAVASCKI (2014, p.139), o qual adota a compreensão de que os direitos materiais tutelados nestas ações não pertenceriam ao ente intermediário que nelas atua e que, por esta razão, não poderiam ser objeto de disposição. A doutrina de GAVRONSKI (2016, p.350), similarmente, considera que, ainda que sejam materialmente disponíveis ou indisponíveis para seus titulares os direitos coletivos em sentido lato, estes serão, como regra, indisponíveis aos entes intermediários.

Ocorre que, nos termos da sistemática processual coletiva brasileira, os interesses difusos, coletivos em sentido estrito e individuais homogêneos são tutelados em juízo por referidos entes intermediários, os quais, conforme o caso, atuarão na qualidade de legitimados autônomos ou de substitutos processuais (THIBAU, 2003). Em outras palavras, como regra, não se verifica a interferência direta dos membros das coletividades interessadas no âmbito da ação judicial. Por outro lado, essa legitimidade dos entes intermediários para representar em juízo os interesses de membros "ausentes" de coletividades é fruto de disposição legal, não havendo, portanto, qualquer aferição casuística da efetiva 'representatividade adequada' do referido ente, como se dá no contexto das Class Actions norte-americanas.

A seu turno, DIDIER JR. e ZANETI JR. (2016, p.304), apesar de não admitirem a renúncia de direitos coletivos materiais pelos entes legitimados, em ações coletivas, sob o argumento de sua indisponibilidade, posicionam-se no sentido de reconhecer o cabimento de autocomposição nestes procedimentos, desde que com limites mais estreitos (como, por exemplo, no caso do reconhecimento da procedência do pedido, quando se encontra a coletividade representada no polo ativo da lide). 
De modo diverso, ainda, se situa a compreensão de THIBAU e REIS (2016, p.198), segundo a qual se poderia cogitar autocomposição envolvendo direitos transindividuais e individuais homogêneos:

Não há dúvidas de que os instrumentos utilizados para a busca de consenso ou acordos entre particulares, titulares de direitos individuais, também podem ser empregados para o alcance do mesmo objetivo entre titulares de direitos coletivos ou seus representantes adequados (no caso do direito brasileiro, estabelecidos pela lei) e as partes que porventura os tenham violado ou ameaçado violar.

Tem-se, portanto, que a discussão acerca da disponibilidade ou indisponibilidade dos direitos coletivos em sentido lato, ou seja, acerca da possibilidade de serem esses direitos objeto de transação, ainda não encontra resposta uníssona da comunidade jurídica, provocando amplo debate. Por outro lado, consoante enunciado n. ${ }^{\circ} 135$ do Fórum Permanente de Processualistas Civis (FPPC) ${ }^{5}$ e como alguns pesquisadores do tema já apontam, sequer seria razoável considerar-se a eventual indisponibilidade do direito material como sendo um óbice intransponível à celebração de negócios jurídicos processuais no bojo da ação judicial em que referido direito é discutido. Isso se dá, uma vez que a celebração de negócios jurídicos processuais envolveria disposição apenas de aspectos do direito processual, ou seja, permitiria tão somente a modulação do procedimento judicial, em nada interferindo no conteúdo do direito material objeto da ação:

Não se vê razão para bloquear acordos ou ajustes processuais, sobre normas processuais ou formas de realização de atos processuais, mesmo nos casos de processos que tenham como objeto direitos indisponíveis, desde que estes acordos não busquem, por vias transversas, dispor sobre o próprio direito material.

Sem embargo, a partir de interpretação do tema permeada pelas diretrizes traçadas no art. $8^{\circ}$ do Código novo, entende-se possível sustentar que pode ser admitida acordos processuais entre as partes e juiz, ainda que o processo envolva direitos indisponíveis, já que neste caso não se estaria a dispor sobre direito material em si, mas regular o modo de condução do processo e realização de certos atos processuais. (ANDRADE, 2016, p.58)

De fato, vislumbra-se o acertamento de mencionado entendimento, na medida em que, já se encontrando os negócios jurídicos processuais celebrados entre as partes sujeitos ao

\footnotetext{
5 "135. (art. 190) A indisponibilidade do direito material não impede, por si só, a celebração de negócio jurídico processual. (Grupo: Negócios Processuais)” (Enunciado n. ${ }^{\circ} 135$, FPPC, editado em 2014)
} 
controle judicial de ofício, para fins de aferição de eventuais nulidades ou abusividades (art.190, parágrafo único, CPC/15), não se justificaria impor restrição legal acerca da disponibilidade ou indisponibilidade do conteúdo do direito material tutelado.

Em primeiro lugar, porque a mera celebração de negócio jurídico processual não deve ser interpretada como ato que importará inafastável prejuízo ao direito de uma das partes do processo: pelo contrário, pode ser mecanismo de garantia de acesso à justiça, com o ajustamento pela ampliação ou redução de prazos processuais ou do tempo disponível à sustentação oral, pela forma de rateio da responsabilidade pelo pagamento de custas processuais, dentre outros:

\begin{abstract}
Em se tratando de convenções atinentes a direitos processuais ou ao procedimento, não há propriamente a disposição de direitos materiais da coletividade. A disposição de direito processual não tem como reflexo necessário a mitigação do direito material cuja tutela é pretendida na relação jurídica processual.

[...] Por esse motivo, a indisponibilidade sobre o direito material não leva necessariamente à indisponibilidade sobre as situações jurídicas processuais, até porque a convenção processual pode reforçar a proteção que 0 ordenamento jurídico atribui aos bens com algum grau de indisponibilidade. (CABRAL, 2016, p.329)
\end{abstract}

Ademais, eventual negócio jurídico processual que desconstruísse o equilíbrio entre as partes perante o processo, ou que indiretamente importasse eventual prejuízo indevido ao direito material cuja tutela é pleiteada por alguma das partes no processo, incorreria em flagrante violação à garantia de devido processo legal e igualdade perante o processo, pelo que não seria considerado válido no controle judicial realizado com base no parágrafo único do art.190, CPC/15. Além disso, como apontado na doutrina colacionada, não seriam os negócios jurídicos processuais instrumentos adequados a veicular disposições indiretas do direito material objeto da lide - conclusão esta que poderia se aplicar a qualquer caso (e não apenas a ações coletivas).

Indícios do acertamento desta compreensão se encontram no próprio fato de que, ao dispor acerca da calendarização do processo (art.191) ou do saneamento compartilhado $\left(\operatorname{art.357,~} \S \S 2^{\circ}\right.$ e $3^{\circ}$ ), não faz menção o legislador do $\mathrm{CPC} / 15$ à necessidade de versar a lide sobre direito que admita autocomposição.

Não seria aplicável, tampouco, argumento no sentido da ilegitimidade dos entes intermediários para dispor, no caso em análise, com base no mesmo fundamento de que, ainda 
que porventura se adotasse compreensão no sentido da eventual indisponibilidade dos direitos transindividuais e individuais homogêneos, não se estaria tratando de disposição dos direitos coletivos em sentido lato, em si, mas de simples aspectos processuais. E se faz inquestionável a premissa de que possuem os entes intermediários legitimidade a atuar processualmente.

Nesse sentido e a título de exemplificação, cumpre trazer a lume a própria Resolução n. ${ }^{\circ} 118$, de $1^{\circ}$ de dezembro de 2014, do Conselho Nacional do Ministério Público, que dispõe acerca das convenções processuais enquanto práticas autocompositivas a serem adotadas no âmbito do Ministério Público ${ }^{6}$ :

Art. 15. As convenções processuais são recomendadas toda vez que o procedimento deva ser adaptado ou flexibilizado para permitir a adequada e efetiva tutela jurisdicional aos interesses materiais subjacentes, bem assim para resguardar âmbito de proteção dos direitos fundamentais processuais.

Art. 16. Segundo a lei processual, poderá o membro do Ministério Público, em qualquer fase da investigação ou durante o processo, celebrar acordos visando constituir, modificar ou extinguir situações jurídicas processuais.

Art. 17. As convenções processuais devem ser celebradas de maneira dialogal e colaborativa, com o objetivo de restaurar o convívio social e a efetiva pacificação dos relacionamentos por intermédio da harmonização entre os envolvidos, podendo ser documentadas como cláusulas de termo de ajustamento de conduta. (CONSELHO NACIONAL DO MINISTÉRIO PÚBLICO, 2014)

Em outras palavras, não se vislumbram, aprioristicamente, obstáculos intransponíveis à aplicação subsidiária dessa sistemática de contratualização do processo no bojo de ações coletivas disciplinadas pelo microssistema, com a condição de que, se valendo do parágrafo único do art.190, seja realizado pelo Poder Judiciário, de ofício ou a requerimento, cuidadoso controle de validade destas convenções processuais, a fim de se garantir a inexistência de abusividades que possam prejudicar os interesses das coletividades discutidos.

\subsection{Um Novo Horizonte ao Devido Processo Legal Coletivo}

Vem se consolidando, sobretudo nos últimos anos, a compreensão de que a garantia de devido processo legal estaria indissociavelmente vinculada à promoção da

\footnotetext{
${ }^{6}$ Nesta seara, vale destacar que, nos termos do art.129, III, da CR/88, é função institucional do Ministério Público promover a ação civil pública em tutela de interesses difusos e coletivos. Da mesma forma, tanto a LACP/85 (em seu art. $5^{\circ}$, I), quanto o CDC/90 (em seu art.82, I), elencam o Ministério Público enquanto legitimado à defesa em juízo de interesses coletivos em sentido lato.
} 
constitucionalização e democratização do processo judicial, que deixa de ser interpretado como uma mera sequência estanque de atos formais, para ser concebido como instrumento de acesso à justiça voltado ao efetivo e eficaz equacionamento de conflitos. Nesse sentido deve ser compreendida a introdução, no $\mathrm{CPC} / 15$, de um modelo processual comparticipativo/cooperativo (THEODORO JUNIOR et al, 2015, p.82) favorecedor da contratualização do processo a partir da celebração de negócios jurídicos processuais.

Com fulcro nessas premissas, pode-se concluir, portanto, que a admissão da modulação do rito das ações coletivas a partir da celebração de negócios jurídicos processuais introduziria no microssistema de tutela processual de direitos coletivos em sentido lato o mencionado modelo comparticipativo/cooperativo de processo, adequando a processualística coletiva aos propósitos de constitucionalização e democratização do processo judicial, almejados pela nova compreensão da garantia de devido processo legal.

ANDRADE (2016, p.54) destaca que o movimento de contratualização do processo recentemente estimulado no ordenamento jurídico brasileiro, busca influência no direito francês, onde a celebração destes negócios jurídicos processuais derivou "para a possibilidade de ajustamento em âmbito coletivo, como se fossem, parafraseando o direito do trabalho, uma espécie de convenção coletiva do processo". Em outras palavras, desde as origens do instituto no direito comparado, este já voltava à negociação acerca de regras processuais que atingiriam coletividades.

Para que a introdução dessa lógica de contratualização do processo, no âmbito das ações coletivas, importe efetiva constitucionalização e democratização do processo judicial, e, consequentemente, contribua à garantia de devido processo legal às coletividades, é indispensável que a celebração de negócios jurídicos processuais das mais diversas naturezas seja seguida de minucioso controle judicial de validade, de ofício ou a requerimento, antes de se prosseguir à homologação, em estreita observância ao art.190, parágrafo único, do CPC/15.

Essa exigência se torna mitigada nos casos de calendarização do processo, haja vista dispor o art.191 do CPC/15 que o calendário dos atos processuais, para ser estabelecido, já deve pressupor a confluência de vontades das partes e do próprio juiz, o qual participará, portanto, da negociação jurídica processual.

\subsection{A Contratualização do Processo na Promoção do Acesso das Coletividades à Justiça}


Entende-se que, caso não sejam constatadas abusividades ou nulidades nos ajustamentos celebrados, vislumbra-se na modulação do procedimento nas ações coletivas importante instrumento à promoção do efetivo acesso das coletividades à justiça. Ocorre que, ao se tornar o processo coletivo mais democratizado, com a ampliação do diálogo entre as partes e o órgão julgador, antevê-se uma tendência à maior aceitabilidade e cumprimento espontâneo das decisões judiciais, bem como à redução do volume de recursos, consoante já citada doutrina de ANDRADE (2016, p.53).

Desconstrói-se a noção de protagonismo único do órgão investido de jurisdição, na condução do processo judicial, oportunizando também às partes expressarem seus interesses. No caso das ações coletivas, em que as coletividades se apresentam como partes, os interesses se encontram sendo representados em juízo pelos entes intermediários, que passarão a ter a prerrogativa de ajustarem no sentido de modular o procedimento judicial, com vistas a viabilizar uma resolução mais célere e efetiva do conflito. Nesse sentido, a ponderação de THEODORO JUNIOR et al (2015, p.289):

O Novo CPC resolve adotar a possibilidade de "negociação" do procedimento; e, com isso, caminha a passos sincronizados com uma concepção mais democrática de processo, valorizando ainda mais um modelo comparticipativo de processo e trilhando uma linha de raciocínio importante para combater o mito do protagonismo judicial.

A inserção de convenções processuais, em instrumentos negociais extrajudiciais, por exemplo, pode minimizar discussões em juízo acerca das atribuições do ônus de prova, a partir do pré-ajustamento entre as partes, no sentido de se atribuir a cada uma a responsabilidade de provar os fatos cujo meio de prova lhe é de mais fácil acesso. De forma semelhante, a calendarização do processo é instrumento eficaz à redução do tempo médio de trâmite processual, na medida em que, estabelecendo prazos diferenciados às partes e ao juiz, e tornando desnecessárias as intimações, reduz os períodos em que o processo ficaria nas Secretarias. Tal fato ensejaria maior celeridade e acesso à justiça.

\section{CONCLUSÃO}

Conclui-se que a possibilidade de celebração de negócios jurídicos processuais foi fomentada pelo $\mathrm{CPC} / 15$, com vistas a se dar concretude ao seu escopo de tornar o processo 
judicial instrumento mais democrático e, como consequência, idôneo a garantir o direito fundamental dos jurisdicionados ao devido processo legal.

Dessa feita, vislumbra-se como positiva e até mesmo necessária a aplicação subsidiária, ao microssistema de tutela processual de direitos coletivos em sentido lato, das normas do CPC/15 que regulamentam a contratualização do processo, com vistas a se tornar mais efetivo e eficaz o acesso das coletividades à justiça, a partir da adequação de cada procedimento que compõe esse microssistema às particularidades da lide e da ampliação da interação entre as partes e o órgão julgador.

Nesse sentido, ressalta-se que não deve ser interpretada como óbice a essa aplicação subsidiária, a condicionante estabelecida pelo art.190 do CPC/15, no sentido de que, para que houvesse negociação jurídica processual, a demanda precisaria versar sobre direitos que admitam autocomposição. Em primeiro lugar, porque não encontra consenso a doutrina acerca da natureza disponível ou indisponível dos direitos tutelados em ações coletivas, tornando-se cada vez mais presentes os entendimentos no sentido da possibilidade de autocomposição nestas ações. Em segundo lugar, porque a própria exigência de que o direito material discutido possa ser objeto de autocomposição é questionada pela doutrina, que ressalta o fato de que a disposição acerca de direitos processuais não implicaria indissociável prejuízo ao direito material discutido, seja ele individual ou coletivo. Reflexo dessa compreensão foi a própria edição do enunciado n. ${ }^{\circ} 135$ do FPPC.

Da mesma forma, o fato de atuarem os entes intermediários, em juízo, como legitimados autônomos ou substitutos processuais não deve ser interpretado como impeditivo da celebração de negócios jurídicos processuais, uma vez que se encontram, por lei, legitimados à plena atuação no processo, em defesa dos interesses transindividuais e individuais homogêneos. Considerando-se, assim, que os negócios jurídicos processuais promovem a democratização no atual modelo de processo judicial, vislumbra-se sua contribuição à implementação, pelas vias do Direito, do acesso à justiça enquanto política pública, ao ampliar os instrumentos à disposição destes 'representantes' da coletividade para a justa promoção dos interesses desta.

Tem-se, portanto, que a admissibilidade de celebração de negócios jurídicos processuais no âmbito de ações coletivas, desde que submetidas a criterioso controle judicial, estaria apta a proporcionar a concretização das garantias constitucionais de devido processo 
legal e acesso à justiça no âmbito da processualística coletiva, ensejando a maior participação e cooperação das partes em um modelo de processo mais democrático.

\section{REFERÊNCIAS BIBLIOGRÁFICAS}

ANDRADE, Érico. A “Contratualização" do Processo. In: THEODORO JUNIOR, Humberto [coord.]. JAYME, Fernando Gonzaga; GONÇALVES, Gláucio Maciel; FARIA, Juliana Cordeiro de; FRANCO, Marcelo Veiga; ARAÚJO, Mayara de Carvalho; CREMASCO, Suzana Santi [orgs.]. Processo Civil Brasileiro - Novos Rumos a Partir do CPC/2015. Belo Horizonte: Del Rey, 2016. pp.47-65.

BEDAQUE, José Roberto dos Santos. Efetividade do Processo e Técnica Processual. 3.ed. São Paulo: Malheiros Editores, 2010.

BRASIL. Lei n. ${ }^{\circ}$ 5.869, de 11 de janeiro de 1973 (Revogada pela Lei n. ${ }^{\circ} 13.105$, de 16 de março de 2015). Institui o Código de Processo Civil. Disponível em: http://www.planalto.gov.br/ccivil_03/leis/L5869impressao.htm - Acesso em 19/05/2017.

BRASIL. Constituição da República Federativa do Brasil de 1988. Disponível em: http://www.planalto.gov.br/ccivil_03/constituicao/constituicaocompilado.htm - Acesso em 12/05/2017.

BRASIL. Lei n. ${ }^{\circ}$ 7.347, de 24 de julho de 1985. Disciplina a ação civil pública de responsabilidade por danos causados ao meio-ambiente, ao consumidor, a bens e direitos de valor artístico, estético, histórico, turístico e paisagístico (VETADO) e dá outras providências. Disponível em: http://www.planalto.gov.br/ccivil_03/leis/L7347orig.htm Acesso em 06/05/2017.

BRASIL. Lei n. ${ }^{\circ}$ 8.078, de 11 de setembro de 1990. Dispõe sobre a proteção do consumidor e dá outras providências. Disponível em: http://www.planalto.gov.br/ccivil_03/leis/L8078.htm - Acesso em 06/05/2017.

BRASIL. Lei n. ${ }^{\circ}$ 13.105, de 16 de março de 2015. Código de Processo Civil. Disponível em: http://www.planalto.gov.br/ccivil_03/_ato2015-2018/2015/lei/113105.htm - Acesso em 18/05/2017.

BRITO, Thiago Carlos de Souza. Saneamento Compartilhado, Nulidades e Preclusão. In: THEODORO JUNIOR, Humberto [coord.]. JAYME, Fernando Gonzaga; GONÇALVES, Gláucio Maciel; FARIA, Juliana Cordeiro de; FRANCO, Marcelo Veiga; ARAÚJO, Mayara de Carvalho; CREMASCO, Suzana Santi [orgs.]. Processo Civil Brasileiro - Novos Rumos a Partir do CPC/2015. Belo Horizonte: Del Rey, 2016. pp.117-134.

CABRAL, Antonio do Passo. As Convenções Processuais e o Termo de Ajustamento de Conduta. In: ZANETI JR., Hermes [coord.]. Processo Coletivo. Salvador: Juspodivm, 2016. pp.319-332. 
CONSELHO NACIONAL DO MINISTÉRIO PÚBLICO. Resolução n. ${ }^{\circ} 118$, de 01 de dezembro de 2014. Dispõe sobre a Política Nacional de Incentivo à Autocomposição no Âmbito do Ministério Público $e$ dá outras providências. Disponível em: http://www.cnmp.mp.br/portal/images/Normas/Resolucoes/Resolu\%C3\%A7\%C3\%A3o_n\% C2\%BA_118_autocomposi\%C3\%A7\%C3\%A3o.pdf - Acesso em 21/05/2017.

DIDIER JR., Fredie; ZANETI JR., Hermes. Curso de Direito Processual Civil - Processo Coletivo. v.4. 10.ed.rev.ampl.e atual. Salvador: Editora JusPodivm, 2016.

FÓRUM PERMANENTE DE PROCESSUALISTAS CIVIS. Enunciados do Fórum Permanente de Processualistas Civis. São Paulo, 18, 19 e 20 de março de 2016. Disponível em: http://portalprocessual.com/wp-content/uploads/2016/05/Carta-de-S\%C3\%A3o-Paulo.pdf - Acesso em 21/05/2017.

GAVRONSKI, Alexandre Amaral. Autocomposição no Novo CPC e nas Ações Coletivas. In: ZANETI JR., Hermes [coord.]. Processo Coletivo. Salvador: Juspodivm, 2016. pp.333-361.

GRINOVER, Ada Pellegrini. As garantias constitucionais do processo nas ações coletivas. In: Revista da Faculdade de Direito da Universidade de São Paulo. São Paulo, v. 82, p. 180-197, jan. 1987. Disponível em: http://www.revistas.usp.br/rfdusp/article/view/67100. Acesso em: 21/05/2017.

THEODORO JUNIOR, Humberto; NUNES, Dierle; BAHIA, Alexandre Melo Franco; PEDRON, Flávio Quinaud. Novo CPC - Fundamentos e Sistematização: Lei 13.105, de 16.03.2015. 2.ed.rev.atual.e ampl. Rio de Janeiro: Forense, 2015.

THEODORO JUNIOR, Humberto. Curso de Direito Processual Civil - Teoria Geral do Direito Processual Civil e Processo de Conhecimento. V.1. 53.ed.rev.e atual. Rio de Janeiro: Forense, 2012.

THIBAU, Tereza Cristina Sorice Baracho. A legitimação ativa nas ações coletivas: um contributo para o estudo da substituição processual. Orientador: Aroldo Plínio Gonçalves. 2003. 295p. Tese (Doutorado em Direito). Faculdade de Direito da Universidade Federal de Minas Gerais, Belo Horizonte, 2003.

THIBAU, Tereza Cristina Sorice Baracho; REIS, Ludmila Costa. Meios Autocompositivos de Resolução de Conflitos Coletivos: Reflexões sobre a Adequação da Técnica em favor da Efetividade. In: Revista Opinião Jurídica, ano 14. n.9. Fortaleza: jul/dez.2016. Disponível em: http://www.calypsoviagens.net.br/index.php/opiniaojuridica/article/view/917/392 Acesso em 20/05/2017.

ZAVASCKI, Teori Albino. Processo Coletivo - Tutela de Direitos Coletivos e Tutela Coletiva de Direitos. 6.ed.rev.atual.e ampl. São Paulo: Editora Revista dos Tribunais, 2014. 